\title{
THE NATIONAL INSTITUTE OF ANIMAL HEALTH, JAPAN
}

$\mathrm{T}$ HE number of publications which nowadays deal with the health of our domesticated and other animals is considerable, but it is not so considerable that a welcome will not be given to a new quarterly journal of animal health published in Japan*.

The scientific research of all kinds now being done in Japan is of high quality, and workers in all countries will be glad to see this new record of research on animal health. The new journal is controlled by an editorial board of twelve distinguished Japanese research workers, and the articles in the first two numbers are all in English.

The first number contains papers by $K$. Tanaka and S. Sato and their collaborators on their electrophoretic studies of tetanus antitoxic horse serum, a paper by Y. Akiyama, O. Asahi and T. Hosoda on the experimental infection of rodents, dogs and cats with Listeria monocytogenes through a branch of the trigeminal nerve; two papers by $J$. Obara and $H$. Nakajima on iron metabolism in equine and infectious anæmia; a paper by S. Kitaoka and A. Yajima which compares the efficacy of the topical application of pesticides used against Boophilus microplus with their application by spraying, and a study of emission spectographic analysis of trace elements in plant materials by T. Hayakawa and a note by K. Shimbayashi on the presence of hydroxyproline in Chlorella pyrenoides. * National Institute of Animal Health Quarterly, Vol. 1, No. 1
(Spring, 1961). Pp. 64. (Tokyo: National Institute of Animal Health, Kodaira-machi, Kitatama-Gun, 1961.)

\section{U.S. SCHOOL STUDENT}

$\mathrm{D}$ URING the summers of 1960 and 1961, the Joint Board on Science Education of the Washington Academy of Science and other co-operating groups conducted an interesting experiment in science motivation and experience for secondary school students. This involved the placing of gifted students in scientific laboratories of the Washington area for an eightweek period of training in research methods. The students received no financial compensation except for a contribution towards their expenses.

The experiment had a modest beginning with 15 students in 1960 when it was financed wholly by local scientific societies. It was expanded to 36 students in 1961, and was financed largely from funds supplied by the National Science Foundation with ancillary support by local societies. It is expected that the programme will be continued in the summer of 1962 on an even larger scale. Leo Schubert, chairman of the Department of Chemistry, Washington University, served as director of the programme, which was centred on his own university. The programme was advertised at virtually no cost, and there were 170 qualified applicants representing 63 schools in the area.

The university provided facilities for a series of orientation lectures at the beginning of the programme and a series of meetings at the end, when the students reported in seminars what they had accomplished during the summer. The unique feature of the experiment was that co-operation was obtained from
In the second number, J. Sasahara and his colleagues publish Part 1 of their work on hog cholera vaccine. This describes the serial passage of a virulent strain of hog cholera virus through laboratory animals; S. Shibata and his colleagues discuss the stability of Brucella agglutinin serum; H. Yugi and his colleagues discuss the sensitization of cattle red cells with tuberculin; S. Kitaoka publishes Parts 4, 5 and 6 of his physiological and ecological work on some ticks, and T. Hayakawa and T. Takayama discuss the effect of the administration of copper and cobalt on the whole-blood copper-level and chronic diarrhœa of cattle.

The emphasis, therefore, in these two issues is on the biophysical and biochemical aspects of the diseases investigated, and this, like research work now in progress in other countries, indicates the marked and valuable trend of modern veterinary research towards a deeper understanding of the exact relation between normal physiology and the biochemical and biophysical disturbances which the veterinarian has to diagnose and try to cure.

All animal pathologists will look forward to future issues of this new journal. It is well printed and attractively produced and it should do much to help the world-wide effort not only to reduce the suffering caused by disease in animals other than man but also, by relating the knowledge thus gained to human disease, to reduce the suffering caused to man.

\section{G. LAPAGE}

\section{RESEARCH PROGRAMME}

research organizations in the area. In this way, the science educational potential of the local research organizations was utilized; the area has more scientists per unit of the population than any other geographical area in the United States. In the laboratories the students were able to engage in genuine research under competent scientists. They were apprentices and had a great deal to learn; no effort was made to treat them as geniuses who had already mastered so much science. It was deemed important to expose them to research and to productive scientists to assist in motivating them towards science as a way of life.

A preliminary effort has been made to evaluate the success of the programme and appears as a report in $\mathbf{a}$ recent issue of the Journal of the Washington Academy of Sciences (11, No. 7; November 1961); an ultimate ovaluation will require years and can be established only in terms of what happens to the students. Without exception, all the students believed the programme to be excellent. They not only learned new skills, but also were much impressed with the discipline of science and the way in which knowledge leads to more knowledge. Of the supervisors, only three felt that their charges were anything less than excellent, and even these commended the programme. The only negative criticism was that the programme was not sufficiently large.

A limited number of copies of a report on the programme are available and may be obtained direct from Leo Schubert. 